Article

\title{
The African Hebrew Israelites of Jerusalem and Ben Ammi's Theology of Marginalisation and Reorientation
}

\author{
Michael T Miller
}

International Consortium for Research in the Humanities (IKGF), Friedrich-Alexander University of Erlangen-Nuremberg, Hartmannstr.14, building D3, 91052 Erlangen, Germany; michael.miller@nym.hush.com

Received: 10 January 2020; Accepted: 8 February 2020; Published: 13 February 2020

\begin{abstract}
This paper will look at the way the African Hebrew Israelites of Jerusalem have utilised the theological narrative of marginalisation in their quest for identity and self-determination. The African Hebrew Israelites of Jerusalem are an expatriate black American group who have lived in Israel since 1969, when their spiritual leader, Detroit-born Ben Ammi, received a vision commanding him to take his people back to the Promised Land. Drawing on a long tradition in the African American community that self-identified as the biblical Israelites, the African Hebrew Israelites are marginalised in their status as Americans, as Jews, and as Israelis. We will examine the writings of Ben Ammi in order to demonstrate that this biblically based motif of marginalisation was a key part of his theology, and one which enabled his movement to grow and sustain itself; yet, in comparison with other contemporaneous theological movements, Ben Ammi utilised a specific variant of this motif. Rejecting the more common emphasis on liberation, Ammi argued for an eschatological reorientation around the marginalised. This article will conclude that Ben Ammi's theology is key to understanding how the community has oriented itself and how it has proved successful in lasting 50 years against both internal disputes and external attacks.
\end{abstract}

Keywords: black Judaism; Hebrew Israelites; Black Theology; African American religions; modern Judaism; new religious movements

\section{Introduction: African American Judaism, the Hebrew Israelites, and Academic Typologies}

The African Hebrew Israelites of Jerusalem (hereafter AHIJ) are a community based in Dimona, Israel, where they have lived since 1969. Originally American, they are part of a broad movement within the African American community which, since at least the end of the nineteenth century, has sought identification not just with, but as, the biblical Israelites. ${ }^{1}$ As such, they are sometimes considered part of what is generally called Black Judaism, ${ }^{2}$ although they reject any identification with the modern Jewish community or practice; the broader movement of which they are part perceives

1 The roots are this movement are entirely African American, emerging at the end of the nineteenth century in the southern USA before spreading quickly across the USA, and then further afield (most notably Jamaica and South Africa); see Dorman (2013) as well as the comprehensive Landing (2002).

2 Landing offers the following typology: "Black Judaism is ... a form of institutionalized (congregational) religious expression in which black persons identify themselves as Jews, Israelites, or Hebrews (sometimes as Hebrew-Israelites) in a manner that seems unacceptable to the "whites" of the world's Jewish community, primarily because Jews take issue with the various justifications set forth by Black Jews in establishing this identity. Thus, "Black Judaism," as defined here, stands distinctly apart from "black Judaism," or that Judaic expression found among black persons that would be acceptable to the world's Jewish community, such as conversion or birth to a recognized Jewish mother. "Black Judaism" has been a social movement; "black Judaism" has been an isolated social phenomenon. Thus, "Black Judaism" will be seen to be more emphatically a black expression than a Jewish one." (Landing 2002, p. 10). 
African Americans as at least one segment of the authentic descendants of the biblical Israelites, while the people commonly known as Jews may or may not be another. ${ }^{3}$ The Judaizing groups who constitute this movement most generally do not name themselves Jews, but prefer to go by the name Hebrew Israelites, or one of a few other variations. There are several factions among them, of varying ideologies and varying degrees of militancy in their outlook.

According to Andre Key's typology, ${ }^{4}$ there are four classifications of Hebrew Israelite groups: the Pentecostal "Holiness Sects" of the early twentieth century; the "Black Rabbinic" who adopt most of the normative Jewish practices while refusing conversion or integration into normative Judaism; the "Torah-only Sects" who reject both rabbinic and New Testament texts; and the "Messianic Hebrews" who accept the messianic status of Jesus, while being essentially Judaizing in practice (that is, they emphasise the Hebraic nature of Jesus' message and its particular or exclusive relevance to Israelites). The AHIJ fall within the latter, but they are notable even within this category because of their understanding that the term "messiah" includes every individual sent by God to bring the Israelites back to the correct way; ergo, not only are many messiahs mentioned in the Bible, but their own leader Ben Ammi is also the messiah for the current age. Therefore, while they read and acknowledge the New Testament as religious literature by and for Israelites, it is not judged as equal to the Hebrew Bible, which is the principle revelation and whose commandments must be kept absolutely. Yet, they also have a new and specific body of revelation: the writings and thought of Ben Ammi.

The AHIJ emerged against the background of 1960's black America, the civil rights struggle and the growing influence of its more militant cousin, the Black Power movement. The community are interesting partly because they have pursued a unique path in attempting to resolve the social issues facing African Americans in the mid-twentieth century: While Malcolm X, Martin Luther King, and other black leaders fought and won some battles for their people, the situation for many black Americans today is still far from ideal; but under the leadership of Ben Ammi the AHIJ took the radical step of migration and established a semi-autonomous society within another state where they could form their own rules and prioritise themselves. ${ }^{5}$ This decision to leave the United States, Landing calls "The single most important factor to confront Black Judaism following World War II"6 In fact, Landing marks them as a unique venture in African American history, all previous attempts at betterment having "lacked any such religious underpinning as this" and, because of their apparent success, "Their ability to take a more meaningful role in their own future has been enhanced considerably." ${ }^{7}$

Several monographs and articles have been published on the community, their history and their lifestyle, ${ }^{8}$ but so far there has been no academic examination of the thought, and the many writings and lectures, of their spiritual leader and theologian Ben Ammi. Between 1982 and 2011, Ben Ammi authored eleven books which developed various aspects of his thought-all of which were published in house. $^{9}$ Scholars often mention and quote selectively from God, the Black Man and Truth, and occasionally from others, but little analysis has been offered. Perhaps the longest sustained

3 Opinion on this question varies between the different Hebrew Israelite factions. The AHIJ have varied in stance but since the 1980s have become more accepting of Jews as part of mutual peace-building with Israel.

4 Key (2014b).

5 "Great African American civil rights leaders, Martin Luther King, Malcolm X and others, had certain principles that they had championed in the midst of our people, but those things were never fully realized there. But we've done more to make real the dreams that they articulated, here [ ... ] We've had the opportunity to forge here a new social, political, economic structure to a whole other standard." Nasikh Immanuel Ben Yehuda quoted in Sheen (2011).

6 Landing (2002), p. 387.

7 Ibid., p. 424.

8 Weisbord (1975); Gerber (1977); Singer (1979); Lounds (1981); Markowitz (1996); Hare (1998); Markowitz (2000); Michaeli (2000); Singer (2000); Markowitz et al. (2003); Markowitz (2005); Könighofer (2008); Jackson (2009); Gagne (2010); Jackson (2013); Elkayam (2014); Avieli and Markovitz (2017); Esensten (2019).

9 Ammi (1990); Ammi (1991a); Ammi (1991b); Ammi (1994); Ammi (1996); Ammi (1999); Ammi (2002); Ammi (2004); Ammi (2005); Ammi (2010); Ammi (2011). 
engagement has been Landing, who quoted passages from the first three texts, concluding that "Each of the works deserves more attention." 10 This article is an attempt to begin fulfilling that need.

Herein, I will analyse Ben Ammi's published writings in order to argue that the community have been successful at least in part because he offered them a way of stepping outside the concepts provided by white America's power structures, claiming the right to define their own identity and place in the world. The motivating principle behind this will be located in his specific focus on the biblical motif of a marginalised people, oppressed by other nations as punishment for their own wrongdoing, but who will ultimately redeem themselves and reclaim their central position. In order to understand this motif and its specific articulation by Ben Ammi, I will place it alongside the contemporaneous manifestation of apparently similar concepts within Latin American and Black Liberation Theologies, and Jewish Post-Holocaust Theology.

\section{History and Background of the African Hebrew Israelites}

In 1963, a Chicago steel worker named Ben Carter (b.1939, d.2014) had been attending meetings of various Black Jewish groups. Having been given the Hebrew name Ben Ammi by a (self-proclaimed) rabbi of one such group, he helped to found the A-Beta Hebrew Culture Center, an organisation intended to bring together the various Judaising African American groups in Chicago. His own major concerns, shared by many but not all, were emigration from America, and a millennial expectation. Some months later, he claimed to have received a revelation from the angel Gabriel commanding him to take his people home to the promised land. By 1967, they had accumulated a number of people (accounts vary from a few dozen to three hundred) willing to make such a journey, and the money necessary to fly halfway across the world. They spent two years in Liberia before entering the young state of Israel, under the Law of Return, in three separate groups. The first group were granted citizenship, but the Israeli government grew increasingly dubious as two more groups successively entered, and refused to convert to Judaism, claiming that they were not Jews but Israelites. This led to some two decades of tension as the state made several attempts to encourage them to leave, to the extent of deporting new arrivals and persistently refusing basic citizen rights such as work permits or housing. The group had dwindled significantly (although a steady stream of new arrivals were also joining them) and were living crammed into the apartments granted to the first two groups in the towns of Dimona, Arad, and Mitzpe Ramon on the edge of the Negev desert, struggling sometimes with internal power disputes and trying to figure themselves and their way of life out, and frequently made aggressively anti-Semitic statements, casting Jews as colonial usurpers of authentic Israelite identity which was in fact black African; and even threatened the imminent arrival of two million black Americans who would "drive out the Europeans."11 Israel for its part would have liked to expel all of them but feared international condemnation and was especially sensitive to aggravating tensions between black and Jewish Americans.

The last three decades, however, have seen efforts on both sides leading to a progressive thawing. Since 2003, most of the community now have at least permanent resident status (meaning they have all rights except those of voting and passports; approximately one hundred have full citizenship) and the youth perform military service. They are now a generally well liked and accepted as part of Israeli society, members regularly writing editorials in HaAretz, for many years running a vegan restaurant in Tel Aviv, and having represented Israel in the Eurovision song contest. They are particularly fond of mentioning that the former Prime Minister Shimon Peres celebrated his eighty-fifth birthday with the community in $2008 .{ }^{12}$

10 Landing (2002), p. 415.

11 On some of the anti-Semitic ideology espoused by the community in the past, see Singer (1979), pp. 185-87.

12 On the relations between Israel and the AHIJ see Miller (forthcoming). 
Their success is not limited to the political realm. The community boasts an impressive longevity and absence of disease, ${ }^{13}$ is "free from drug abuse, poor health and violent crime"14, and in general that it has achieved a complete turnaround from the American world of "rampant disease, drug abuse, sexual abuse, corruption, ecological destruction, disintegration of the family unity", ${ }^{15}$ all within a society that did not respect or accept them. For the members, these successes "are read as signs—or further proof-that confirm God's favour, support the rectitude of Ben Ammi's program, and validate the biblical sources that document 'who we are as a people.'"16

\section{Marginality and Theodicy}

The theory of marginality, developed by Robert Ezra Park and Everett Stonequist last century, has emphasised the in-betweenness of marginal groups and individuals. In their reading marginality consists of being dislocated from the centre of multiple groups by dint of not belonging solely to any one of them. Stonequist writes that "The marginal man ... is one whom fate has condemned to live in two societies and in two, not merely different but antagonistic cultures .... his mind is the crucible in which two different and refractory cultures may be said to melt and, either wholly or in part, fuse."17 This aptly describes the AHIJ, as a community who stand in between the African American and the Jewish. However, the marginality I am interested in is one not of in-betweenness, but of dislocation from the centre into the periphery; of communities that are expelled from the mainstream and exist on the margins of majority society. This is the marginality which has been explored over the last sixty years by liberation theology, in its various articulations.

Emerging in Latin America and the USA in the 1960s, liberation theology emphasises the central responsibility of the Church towards the poor and oppressed-the marginalised in society. Classical (Catholic) liberation theology, as espoused by Gustavo Gutiérrez and Juan Segundo among others, and formalised at the meetings at Medellín, Colombia (1968) and Puebla, Mexico (1979), has focused principally on the poor ${ }^{18}$ and has utilised Christian scripture (both Old and New Testament) to support this emphasis. Gutiérrez explains that one encounters God through encountering others:

We find the Lord in our encounters with others, especially the poor, marginated, and exploited ones [ ... ] with those whose human features have been disfigured by oppression, despoliation, and alienation and who have 'no beauty, no majesty' but are the things 'from which men turn away their eyes' (Isa. 53:2-3). ${ }^{19}$

This emphasis on the marginalised has been potent in restructuring the priorities of the Catholic Church in particular, but liberation theology is not limited to that. At the same time, James Cone was developing Black Theology in the USA in response to the conditions of African Americans, and subsequently the motif has been developed with reference to many different communities who feel that they exist on the margins of society or the world. David Batstone et al. have put it as follows: "At its roots, liberation theology attempts to rebuild theology in view of the history of massive suffering produced by empire and to affirm marginalized faith communities in their creation of a new humanity." 20

\footnotetext{
Elkayam (2014), esp. n.22 (p. 322).

Ben-Israel (1996).

5 This is how the Western world is typified at the About Us: Why Israel? Section of the Community's Website http: //africanhebrewisraelitesofjerusalem.com/?page_id=2 (accessed 5 March 2019). Jackson (2013) also discusses the perceived pathology of African American culture.

16 Markowitz (2005), p. 332.

7 Stonequist (1937), p. xv.

Puebla expressed this as a "preferential option for the poor" (Puebla document 4.1).

Gutiérrez (1988), pp. 115-16.

Batstone et al. (1997), p. 1.
} 
Cone was an academic theologian and vocal advocate of the Black Power movement. Beginning with Black Theology and Black Power (1969) ${ }^{21}$ and A Black Theology of Liberation $(1970)^{22}$ Cone articulated a theology from the African American perspective, including the writing of (political, though not necessarily racial) blackness into the figure of Christ as representative of the contemporary oppressed. His principle concern was African Americans, and he found inspiration for their struggle in the Hebrew Bible and New Testament.

The marginalised communities are the centrepiece of liberation theology's soteriology, because "The salvation of humanity passes through them; they are the bearers of the meaning of history and 'inherit the Kingdom' (James 2:5)." ${ }^{23}$ In fact, "It is and ever shall be the poor who are makers of history."24 And so the captivity and liberation of the Israelites forms the paradigm for understanding the struggle of all oppressed.

So, liberation theology is particularly concerned with "the nonperson," ${ }^{25}$ where that term denotes "those human beings who are considered less than human by society, because that society is based on privileges arrogated by a minority." ${ }^{26}$ For the liberation theologians,

It is the exploited segments of society, the despised ethnic groups, the marginalized cultures, the persons we may know in their energy and vitality only by looking at them from the underside of history-in a word, those whom the Bible calls 'the poor'-who are the historical agent and repository of this new understanding of the faith. ${ }^{27}$

As such, I will argue in this article that Ben Ammi's theology exists as a form of liberation theology, sharing in its utilisation of scripture, in its social concerns, and in its core motifs. However, I will show that Ben Ammi's thought has some unique aspects which differentiate it from the classical formulations of liberation theology, such that both the kind of liberation, and its eschatological significance, is different. Ben Ammi's notion of liberation from marginality in fact demands a remapping such that the margins become centre.

Before delving in Ben Ammi's theology, it is worth noting Andre Key's recent work on the issue of theodicy in Hebrew Israelite thought. ${ }^{28}$ This constitutes the first detailed investigation of Hebrew Israelite theology so far, although it does not include the AHIJ or Ben Ammi. A core component of the theology is what Key labels as "the theodicy of deserved punishment". ${ }^{29}$ This is a theological motif which "locates with Black people a chosen role within God's destiny for humanity." And is expressed as "Curse Consciousness":

Curse consciousness is the over-determining belief that any action engaged in by Blacks will ultimately fail if it is not 'ordained by God.' Cursed consciousness is the surface manifestation of ... the real foundation of Black Judaism—namely, the theodicy of 'deserved punishment. ${ }^{\prime 30}$

Because of this,

The question of ethnic suffering stands at the center of the Black Judaism. It serves as an entry point into the analysis of the faith. It can be argued that Black Jews and Hebrew Israelites are attempting to accomplish three tasks: (1) first reclaim a lost African identity, (2) come

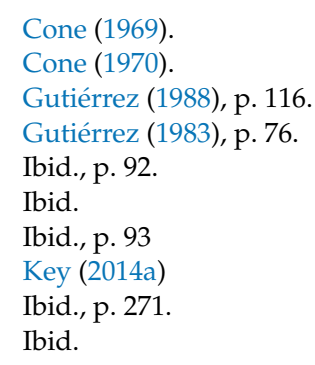


to terms, theologically, with the involuntary presence of African people in the Americas, and (3) articulate an understanding of the divine that supports their liberation. ${ }^{31}$

Key looks in depth at this theme in three authors-Cohane Michael Ben Levi, ${ }^{32}$ Rudolph Windsor, and Moses Farrar-locating in them all a dependence upon a specific exegesis of Deuteronomy 28. This chapter provides a list of curses to be enacted upon the Israelites if they fail to obey the laws given by God. These are understood as predicting - and justifying — the American captivity. Key views the Hebrew Israelite theodicy unfavourably, terming it a "theological dehumanising ... which places Black people in the position of justifying their humanity through cosmologies of wretchedness", 33 where:

Black Judaism functions as a mis-religion by asserting that Black people are incomplete until they accept their lost identity, lost God, and lost religious duty. Furthermore, by raising the issue of deserved punishment as a theodicy, Black Hebrews have necessarily opened the door to the charge of divine racism. ${ }^{34}$

This then "places the entire onus of liberation on Black people, through a set of requirements that lack the tools for measurement." 35 The argument here is that Hebrew Israelite thinkers have indulged in a theology which actively disempowers African Americans, placing the responsibility for their suffering not on the actions of white society, but on their own failings; this internalised victim-blaming only serves to justify further suffering, as the price that a God who only cares about the faults of one ethnic group continues to punish them. Key criticises Hebrew Israelism as a whole for failing to articulate a real solution to the plight of black America's woes, the closest being AHIJ's veganism which promotes good health; so, "Ultimately, it can be argued, that the theodicy of deserved punishment has prevented the opportunity for there to be a Hebrew Israelite-led social justice movement." 36

Herein, I will argue that while Ben Ammi utilises the same theological background, including the exegesis of Deuteronomy $28,{ }^{37}$ his theology demonstrates some important additional aspects which mitigate Key's criticisms.

\section{Marginalisation in Ben Ammi's theology}

I will now turn to the thought of Ben Ammi, in particular his argument for a certain kind of salvation history grounded upon an ongoing marginalisation of his people. I will argue that although he builds upon oft-used texts and traditions, Ammi interprets them in an idiosyncratic way which not only foregrounds the particular marginalised group he is concerned with and paves the way for their liberation, but predicts an eschatological reordering wherein the margins become centre, and centre becomes margins.

Throughout his writings, Ben Ammi presents the present age as the turning point in a historical struggle between the people of Israel and the Euro-gentiles. ${ }^{38}$ The past two thousand years (since the Roman conquest of Judaea and the expulsion of the Israelites) have been a gradual entrenching of Euro-gentile domination over the globe and their suppression of the truth about the Israelites. This has

\footnotetext{
Ibid., p. 272.

Ben Levi became a member of the AHIJ in 2005, eight years after the text analysed by Key; see Jackson (2013), pp. 116-17. Key (2014a), p. 285.

Ibid.

Ibid., p. 286.

Ibid.

7 Lounds (1981), pp. 38-40 quotes a member of the group at length on the biblical prophecies. Another example of the AHIJ's use of this is discussed by Markowitz (2005), p. 330.

38 All of Ben Ammi's books begin with an explanation of terminology including the compound term "Euro-gentile." This is defined as "a people or nation that is without the knowledge of the True and Living God of Creation" and specifically "the entire European family of nations" from America to New Zealand.
} 
led to the increasing marginalisation of the people until their final degradation when they were taken into slavery in the Americas—-the new iteration of Egyptian and Babylonian captivity. ${ }^{39}$

This progressive marginalisation, or dislocation of the chosen people out of the spotlight, is the centrepiece of Ammi's theology. African Americans had been progressively peripheralised:

Black people were initially chosen by God to guide the world out of its state of ignorance, but instead they chose to join the world of iniquity. Because of their provocation of God, Black people are not only abhorred by all nations but are foolishly out of step with the rhythms and patterns established by God for perfection in each of their lives. ${ }^{40}$

"The transfiguration of the African Hebrews (Sons of God) into a non-people (negroes) exemplifies the epitome of soul transformation. The people who were once rulers of advanced civilizations like Songhai, Egypt and Mali have descended into the pits of the most barbaric societies." 41

And now they are "the laughing stock of the world, disrespected by all people." 42

In these passages Ben Ammi explains the position of black Americans to be the lowest of all, a "non-people" "disrespected by all"; and the reason for this is found in their "provocation" of God and their rejection of his favour.

Ben Ammi's mid-career text An Imitation of Life, develops the theme intensively and argues that, via the Euro-gentiles, satan ${ }^{43}$ has pulled off an ingenious scheme to replace the image of God (the true spirit which Adamic humankind was intended to embody, to manifest and live up to), with a satanic image, one which led not to life but to death. Ammi delineates the three aspects which were concealed/altered in order to subjugate the Israelites and promote the satanic agenda, as (1) names of individuals (replacing African Israelite names with European ones), (2) history of the Israelites (the concealing of the identity of the African slaves' true history as the people of Israel, making them lost and rootless among nations), and (3) the nature and path to the God of Israel, which was the key to their salvation. ${ }^{44}$ I will now look at these three themes.

\subsection{Deracination and Language/Naming}

Slaves were routinely named by their masters; if they had a name already, they were renamed. The names given would be Western ones that the masters were familiar with. This use of Western names by African Americans has largely continued since emancipation.

The replacing of slaves' traditional African Israelite names with Western ones served a crucial function which Ben Ammi calls "deracination": the stripping of the people's racial nature, both as a group and as individuals. Claiming that a people must be connected to its past via language in order to be true to itself, Ammi understands the removal of traditional names as a deliberate attempt to sever the individuals and the collective from their culture, history, and land: the aim was "to obscure and undermine any possibility that their positive achievements could be attributed to Africa", ${ }^{45}$ so that the identifiers of any achievements made by the slaves pointed back to Europe instead. Even the identifier

39 This theme is not unique in Ben Ammi's writing. Indeed, Landing (2002), pp. 412-13 argues that much of the damning narration of African American degradation at the hands of whites can be found in the earliest manifestations of Black Judaism in Crowdy, Ford, et al, although the dependence is not something consciously understood by Ammi or his followers.

40 Ammi (1990), p. 141.

41 Ibid., p. 152.

42 Ibid.

43 Ben Ammi never capitalizes satan. For him it is not a proper name, just a noun, one designating the spirit of evil that can be embodied by human ideas and actions; see below.

44 Ammi (1999), p. 26

45 Ammi (1990), p. 144, cf. (1999), p. 25. 
"negro" was a way of disassociating the people from Africa, a Spanish term which lumped all slaves (Israelites and non-Israelites) into the same mass. ${ }^{46}$

In the culmination of this process, "Everything connected with the color black, no matter whether it was race, religion, or culture was labelled base, backwards and uncivilized" ${ }^{47}$ The acceptance of the title "negro" demonstrates exactly how far the slaves and the Black race were subdued, were spiritually broken as part of their marginalisation, of their removal from the new centre to the outskirts of value and meaning. And this has led to the twentieth century where "African Americans are nameless, landless, without a language or culture of their own." ${ }^{48}$

\subsection{History}

This deracination and renaming could only work in concert with an effort to conceal the actual proud history and nature of the African Israelites. So, Ammi argues, the true history of the people now known as African Americans, their identity as the people Israel of the Hebrew Bible, has been deliberately concealed and distorted: "our history ... was altered to conceal our true identity ... Being that you are descendants of the biblical Israelites your history is permeating all things effecting your existence in the American captivity." 49 This loss of connection to the past is then linked with the contemporary plight of African Americans: "Your inability to relate to a definite pre-slavery history is coupled to your inability to end your captivity." 50 This is linked historically to the Catholic Church's ban on reading the history of the Israelites, the Old Testament, ${ }^{51}$ and their subsequent degradation of it as irrelevant, superseded by the New. ${ }^{52}$ The Euro-gentiles have spread a false history, wherein the African has no relation to the Israelite; the people of the Bible and of the covenant were white Europeans not black Africans; and the African is nothing more than a slave. Through this narrative the African was self-alienated, "disconnected from our very soul" 53 and desired to be something else than what they were (i.e., they wished to be white).

Ammi calls this a "genocide of the mind". ${ }^{54}$ And at least some of this is consciously pursued by white society:

In actuality, the Bible scholars, the picture selectors, the image makers, the movie producers and religious scriptwriters have perpetuated the deception of a white Jesus for hundreds of years. They are fully aware that Jesus and the ancient Hebrews were not white. But the white establishment had no intention of letting African Americans know the truth. ${ }^{55}$

46 Ammi (1990), p. 159. This passage comes immediately after the most explicitly classic anti-semitic passage I have found in Ben Ammi's writings-that "one segment of the European slavemaster college" knew the power of names as found among the Goldbergs, Weinbergs, Silvermans, Diamonds and Weismans who "have all profited monetarily ... The spirit behind their names has manifested itself into a rewarding control of the world's economic systems." (p. 146) It is unclear whether Ammi intended the implication, which is hard to miss, only because he does not go further and make an explicit point about this being the same Euro-gentiles who claimed Israelite heritage for themselves; Ammi was not one to mince words or allude when something can be plainly stated.

47 Ammi (1990), p. 143.

48 Ammi (1990), p. 145.

49 Ammi (1999), p. 26. This theme of concealing is found also in the Nation of Islam. See Lincoln (1973). Other similarities include the focus on diet and health, and the banning of alcohol and tobacco, although these ultimately descend from Noble Drew Ali's Moorish Science Temple.

50 Ammi (1999), ibid.

51 Ammi (1999), 20.

52 Ammi argues that Gentile Bible interpretation obscures the original meaning, which is obvious when read in the Hebrew: (1990), p. 107-8.

53 Ammi (1990), p. 155

54 Ammi (1990), p. 159.

55 Ammi (1990), p. 163. 


\subsection{Religion}

The most devastating of these three, however, has been the last. Ben Ammi avers that the religious practice of African Americans has been manipulated so that it worships not the God of Israel, but rather an idolatrous image which is strangely redolent of the Euro-gentiles themselves: "The Euro-gentile changed our God and manner of worship. (... ) Love and true worship were redefined and shifted from Yah, the God of Creation, to gods made in the image of our captors". ${ }^{56}$ And so, "He [the Euro-gentile] gave us a degenerative history, manner of worship and god. These were the critical components used to maintain our captivity", 57 and they achieved this because the "deep-seated deception involved in our religious practices [ ... ] have led our people astray from God". ${ }^{58}$ That is to say, the mental slavery has continued even after physical slavery was abolished because the people were indoctrinated into a false spiritual paradigm which led them in the opposite direction to the path of salvation and redemption. Therefore, inferior status has become embedded within the minds of the oppressed: "This civilization's very subtle process of oppression has molded its victims into functional inferiors thus better enabling satan to implant his image and misconception of God and living in their minds." 59

Once the African Israelites were taken into America, the pseudo-religion of Christianity, the "slave-oriented Christianity" which, in Ben Ammi's reading, Jesus himself warned of in Matthew $24: 5,{ }^{60}$ was forced onto them. This was key to their further demise, even though it was presented as their salvation-the anointed African Hebrew prophet Yeshua had been whitewashed and translated into the Greco-Roman god-myth Jesus Christ. ${ }^{61}$ Now, people are worshipping satan in disguise because ideas derived from European paganism are being presented as monotheistic and righteous under the name Christianity and its assistant, liberal democracy:

The Euro-gentiles have used the 'Power to Define' to halt the process of conscious human development. The Euro-gentile, anti-Yah civilization proceeded to blot out Truth, to define darkness as light ... paganism as worship of Yah, a faith without works ... and our captivity as our freedom ... [Therefore] liberal democracy poses the greatest threat to the continued existence of the human family on this planet earth. ${ }^{62}$

Liberal democracy, as the contemporary outgrowth of Euro-gentile Christianity which talks much about freedom without any conception of the consequences of unrighteous actions, is a particular bugbear for Ben Ammi, and its articulation in America he attacks repeatedly, reserving special condemnation for its persistent—even, legislated—breaking of each of the Ten Commandments. ${ }^{63}$

Crucially though, it is not just the righteous people who have been marginalised and concealed; it is truth itself. Ben Ammi discusses this throughout his writings, that humanity in general and the Israelites in particular have been fooled by "The Great Religious Conspiracy". ${ }^{64}$ The conspiracy has concealed and replaced the true ways of God (and way to God) with an imitation, a system of idols and lies which confuse people and prevent them from really connecting to the source of life and righteousness.

The marginalisation and concealing of truth have meant a wholesale replacement of the divinely ordained natural order. Examples are spread throughout his work, and include (1) the temporal:

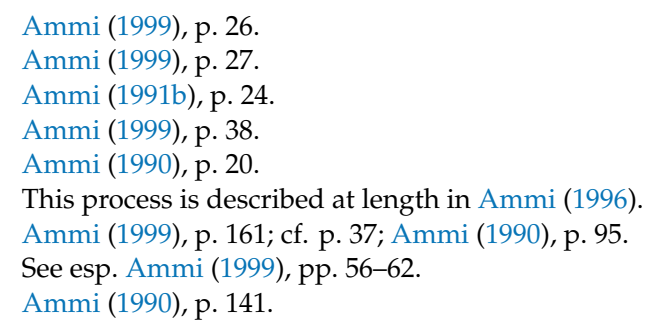


calendar, seasons, days of the week, and months of the year; ${ }^{65}$ most specifically the replacing of Shabbat with the pagan invocation of Sunday, ${ }^{66}$ but also the relocation of beginning of the week, the months $s^{67}$ (which are no longer in sync with the new moon), the year (beginning in winter instead of autumn) ${ }^{68}$ and the day (at midnight rather than sunset). ${ }^{69}$ The most important American celebrations, "New Year, Easter and Christmas - every one a pagan holiday" and now in service to commerce. ${ }^{70}$ (2) The religious: The curse of Ham as applied to Africans rather than Canaan; ${ }^{71}$ the Hebrew people (and Jesus) as white Europeans, ${ }^{72}$ the fulfilment and therefore irrelevance of the Hebrew scriptures and law; ${ }^{73}$ God as European, angels as women in nightgowns, heaven and hell as far away places rather than states reached in life, ${ }^{74}$ judgment and reward found after rather than within life, and belief rather than actions as the crux of righteousness; ${ }^{75}$ idols (crucifixes and images) as the path to God; ${ }^{76}$ worship as something isolated in one day of the week separate from daily life; ${ }^{77}$ and the promotion of evolution which represents the most "concerted effort by the Euro-gentiles to destroy the Genesis account of the creation".$^{78}$ (3) The political: War and constantly evolving weaponry as necessary for peace, ${ }^{79}$ an emphasis on the individual's freedom to disobey God's guidance, ${ }^{80}$ and finally, the deterioration and abandonment of traditional gender and family roles. ${ }^{81}$

\subsection{The Power to Define}

A crucial part of Ben Ammi's socio-theology is 'The Power to Define'. John Jackson describes it as "a commitment to renaming objects and ideas in direct opposition to standard definitions",

65 The destruction of nature too, trees et al "are the victims of devil worship" (Ammi 1990, p. 189). Ammi's environmental concerns are clear when he criticises even the wastefulness of three friends each buying identical newspapers which will be discarded after thirty minutes of reading (1990, p. 190).

66 Ammi (1990), p. 194; (1999), p. 40. "We can vividly see one of the ways satan has deceived the whole world, as the people unknowingly give honor to no less than seven false pagan gods in the course of one week." (1990, p. 151).

67 Ammi (1990), p. 193.

68 Ammi (1990), pp. 150, 193.

69 Ammi (1990), pp. 122, 193; (1999), p. 40.

70 Ammi (1990), p. 194, (1991b), p. 25. Ben Ammi argues that Jer.10:2-5 is an explicit warning against Christmas trees (1982, p. 196).

71 Ammi (1990), p. 21.

72 Ammi (1990), pp. 22-23, (1999), p. 40. This in particular has been a deliberate and persistent policy of spreading lies via movies, missionaries, Broadway shows, TV, and current affairs magazines, (1999), p. 99. Ammi (1996) discusses at length the implications of the Greek name Jesus Christ as a replacement for the obviously Hebrew original Yeshua (cf. 1999, pp. 3-4); Allowing Christian blacks to call on the Hebrew Yeshua "would have kept them in the arena of Truth, hope and reality. At the least, it would have kept them in touch somewhat with a God that could help them the God of their fathers-the Almighty, Holy One of Israel." (1991b, p. 24). In fact all the important titles have been mimicked and distorted by the church; the holy space of terms such as Son of Man "has been occupied by the imitation purposefully to prevent the Sons of Light from finding comfort and spiritual advantage by the use of the term." (1999, p. 111).

73 Ammi (1990), p. 23; (1999), p. 40.

74 Ammi (1990), p. 61.

75 Ammi (1990), p. 122, (1999), p. 40. Connected with a paradoxical ascending to heaven after death, while death is always connected with descent in scripture, (1990), p. 230.

76 Ammi (1990), p. 62.

77 Ammi (1999) p. 109. Ammi explains that in the Hebrew Bible there is just one word, avodah, meaning both work and worship; this means, he says, that you worship God by the work you do throughout the six days of the week not spent resting, (1990), pp. 105-38.

78 Ammi (1999), p. k; p. 18.

79 Ammi (1990), p. 61

80 Ammi (1990), pp. 78-79.

81 "Today's average family as well as the typical male/female element within the community is actually the element I would consider tantamount to hell on earth in which we find men afraid to be overly masculine and women preferring to assume the role of men." (Ammi 1991b, p. 126). Feminist aspiration to equality "has become suspiciously synonymous with 'sameness'." "The evil element's goal is to create a genderless society and completely interchangeable roles." (i.e., to destroy the elements of male and female). The order instilled by God has been violated and we have been ejected from the everlasting "halted human development and brought in a cycle of time called confusion", (1991b, p. 127). We must "structure families based on Truth, a sense of respect and accountability to the laws governing the cycles of life." (and not include lovers or gay partners as family). Gender roles in the family are natural, though they can be temporarily suspended. Male and female natures must be met correctly or they will become perverted. "There is a mood, a temperament and behaviors that is essential and has to accompany all role models for both men and women." (1991b, p. 128). 
something which the community "constantly affirm" in their lives, and is "central to their entire global agenda and spiritual mission." 82 Described at length in God, the Black Man and Truth, the Power to Define is "the ability to discern and the will to interpret and implement ideas and philosophies in order to be totally victorious against one's enemy." 83 It is the right and the ability to impose a framework, an interpretation upon the world and to determine that this is how things are. It is the ability to break free from concepts designed by others, especially by those who are not sympathetic to one's community, to one's well-being, to one's priorities or values, and to decide for oneself according to one's own criteria what the hierarchy of values are and what the best way of life is. As such, it is a crucial tool in self-determination and in the construction of a healthy and self-beneficial society: "We who have freed ourselves from the Euro-gentile's power to define, define for ourselves, speak for ourselves and name ourselves and thereby control our destiny." 84

Clearly, the Power to Define can be used for good or ill, and the centuries during which the Euro-gentiles held it were disastrous: They presented their definitions of "God and salvation, life and death, heaven and hell, the resurrection, worship and sin, the wise and foolish, rich and the poor, the happy and the sad, the righteous and the wicked. The objective of these definitions was to conceptualize a Euro-centric god and salvation". ${ }^{85}$ Thus the mythical pagan ideas which actually pull one away from God and truth became a part of Christianity. The true voice of God had become suppressed, yet this is the only voice capable of saving humanity.

The reclamation of the Power to Define is understood by Ben Ammi as the principle achievement of the African Hebrew Israelites: having liberated themselves from America, they embarked on a still ongoing project of rethinking and renaming the world and their place in it. So,

As we start the journey back, we will find our people clothed with ungodly lifestyles, symbols and perverted Euro-gentile wisdom. There has to be an undressing piece by piece until we arrive in Genesis naked (innocent) and pristine before God, that He may redress us in Holiness. ${ }^{86}$

It is via the Power to Define that Ben Ammi wants to overturn the "Era of the Great Deception"87 which began when the holy scriptures first entered Europe, and reorient first African Americans, and subsequently humanity, around a new conceptual structure. In one particularly potent passage which deserves analysis, he writes:

In the beginning, the Creator set forth the "Way of Life" for man. Man was to live and function within the cycles of life. Then, deceived by satan, man began to feel that he had his "own mind," not understanding that man was created in the image of God and given the "God Mind." Now, man finds himself trapped in the pit he has dug. He has to now seek to understand God's Divine cycles, seasons and set times and be obedient unto them. This will bring about the purifying of his body and mind, allowing God to return to his temple. [ ... ] The Plan of God through the Kingdom of God, is to return man to Truth and Truth to man [... ] The Kingdom of God is dedicated to the restoration of man to God Almighty and His Divine plan of life. Through teaching and living the Divine laws, statutes and commandments, every man may know how to live in harmony with his part of the plan, keeping him in place with the eternal plan of the Creator as it has been charted by Divine prophecy. ${ }^{88}$

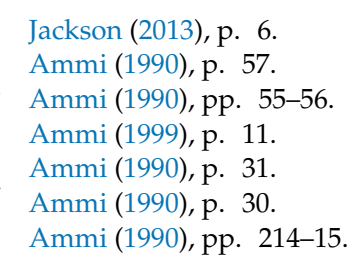


Here, Ben Ammi explains that there is a specific, divinely ordained way of life for human beings, one which brings the natural benefits of being in tune with the cosmos. Ben Ammi's ontology is based around a concept of God as the spiritual foundation of life and reality-God, as spirit, is prior to substance and is the thought which instigates substance and which grounds it, making it what it is; hence without this conceptual link back to its nature any substance will disintegrate and ultimately die. ${ }^{89}$ Life is ultimately to be found only through closeness to God, and obedience to God's diktats-anything else leads to death. Ammi posits this as an interpretation of the serpent's incursion in Genesis 2: the fruit that the serpent tricked Eve into eating, which will bring death, though not immediately, is metaphor for the path of sinfulness, disobedience, and spiritual distance from the source of life, God. ${ }^{90}$ The serpent represents the alternative spirit which humans can choose to embody through their lives and actions, that which does not lead to life, health, and success, but to deterioration. This choice, to embody the spirit of disobedience/death rather than the spirit of God/life is one that all humans and all societies face. The concealing of the natural order and the cycles which contextualise human life are a part of the satanic path, and as a result of the primordial error, everything in the human world now is wrong, and everything leads to death instead of to life: "No force functions as it did under the Divine authority of God. Everything now enhances death. The polluted minds of evil, controlled by satan do not even allow the land, air and water to perform their life-giving tasks for man." ${ }^{\prime 1}$ This path, being adverse to God, is of the devil; the recent history of African Americans, even more so than the Euro-gentiles of whom they have become a radicalised parody, demonstrates aptly for Ben Ammi that they have been pursuing just such a path.

If the path of sin is that of emulating and embodying satan, then God is the spirit which humans were made to emulate, that which they should try to express in their own lives. In expressing and embodying this divine spirit they will grow and live..$^{92}$ The ultimate goal, and the original intention of human existence, is eternal life; once righteousness is reclaimed, then, "Life spans will first be comparable to those in the book of Genesis, then on to everlasting life." ${ }^{\prime 93}$ Death, after all, was originally a punishment-or natural consequence-for disobedience: it was not the original plan that Adam and Eve would die. So, while there are "specific cycles and laws for man to live by" (i.e., those given in the Torah), which all are crucial to health and well-being, breaking them is as detrimental as interrupting or distorting the nine month gestation period. ${ }^{94}$ The return to these will herald a return to everlasting life, but this redemption is not only for the Israelites; it was all of humanity which fell, and all who will be redeemed, because "In the millennial age participation in the Kingdom of God is the natural birthright of everyone." 95 Thus, "we have taken the Power to Define into our own hands and the results will be freedom for all men." ${ }^{\prime 96} \mathrm{In}$ fact, it is all of reality which is now bound to be reoriented around life rather than death and so the reorientation will benefit "to your personal health and well-being but [also] that of the entire planet." ${ }^{\prime \prime 7}$ Ben Ammi sees the Hebrew Israelites' rediscovery of and return to righteousness as pivotal for everyone.

The role of the Israelites/African Americans in this, is to spearhead the revolution; they are destined to take their place at the forefront of the cosmic drama and function as a light to the gentiles, leading the world out of its self-deception and death-obsession. This responsibility to all of humanity is articulated clearly by Ben Ammi when he writes,

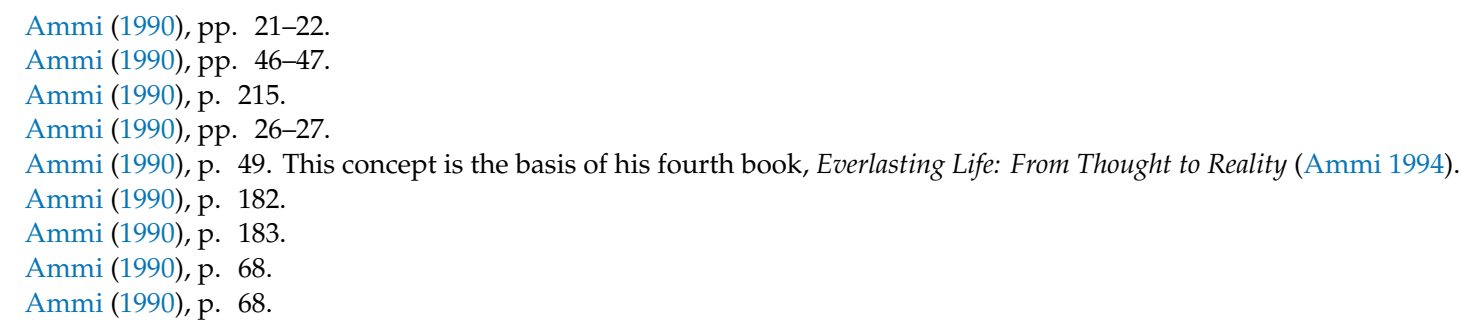


God's chastisements were devastating and sure. That erroneous decision not only negatively affected the Children of Israel, but by shirking their Divine charge, they caused all nations and people's dreams of living in a utopian paradise, where harmony, justice and love prevailed to be deferred. ${ }^{98}$

So although the Euro-gentiles were used to punish Israel, they too have actually been victims of Israel's error; "because the Children of Israel dodged their responsibility to be Godly leaders and pacesetters, and failed to show others the benefits of righteous living, all men were denied the glory of a world where governments were headed by men governed by God." ${ }^{\prime 99}$

So now, it is the responsibility of the Israelites to reassess everything which has been told to them by Euro-gentile civilisation. Invoking the second chapter of Genesis in an attempt to show the pivotal point we now inhabit, Ben Ammi posits his community as retracing our steps to the Garden of Eden in order to undo the primordial fall: "We must question every facet of existence under Euro-gentile domination. All things must be brought to the Sons of God as they were brought to Adam, for naming and renaming." 100

Finally, before moving on, we should note that Ben Ammi is an intensely immanent thinker; he despises any attempt to place God or the locus of spirituality in some abstract or otherworldly realm. His thought and writing are entirely about this world and this life, and he is adamant that this is the original intention of the scriptures. ${ }^{101}$ As such, Ben Ammi's definition of God as a "spirit" is explained in common sense terms as something that can be expressed by human actions. ${ }^{102}$ Interpreting Genesis, Ben Ammi claims that the image of God means that human beings are created with this image as something to live up to, something they should embody-Adam was intended to be the "earthly image, likeness-form of Yah"103 — and doing so will bring all the benefits of life, health, well-being. But if humans do not embody that spirit, they will embody something else. In embodying a spirit other than God, the source of life and bounty, humanity is inevitably binding themselves into death and dis-ease, as is explained by God in Genesis when warning Adam and Eve that if they disobey and live by their own rules rather than His, they "shall surely die" (Gen.2:17). The misfortunes and discomforts of twentieth-century African Americans, even after the legal emancipation, are explained as the legacy of an ingrained mindset that worships death and is practiced throughout everyday life in the unhealthy diets, frequent drug, alcohol and cigarette use, etc.-all of which are simply rooted in the imposed Christian emphasis on other worlds and the degradation/de-emphasis of this one as a mere ante-chamber.

\section{Comparison of Ben Ammi's Theology of Marginalisation with Others}

Ben Ammi's theology is based upon the belief that African Americans are descendants of the biblical Israelites, and their experiences are understandable through the lens of biblical prophecy. Because the Israelites forgot God and his commandments, the curses outlined in Deuteronomy 28 were

98 Ammi (1991b), p. 17.

99 Ammi (1991b), p. 17.

100 Ammi (1990), p. 61. This concept was emphasised in a short document by Ben Ammi temporarily available through the community's website, titled The Ascension of the New Adam (n.d.), which states "Herein is the conclusion of the matter: from henceforth and forever, all Hebrews/Hebrew Israelites (and their offspring yet born), are to distinguish themselves as-and be distinguished as - the "ascendants of the New Adam" [... ] As we maintain these righteous rhythms, cycles and seasons, holding fast to our alignment with the will of Yah, we activate and bring into being the fulfillment of the legacy and heritage promised unto His sons and daughters." (pp. 7-8)

101 In this he parallels James Cone, who writes that "The most corrupting influence among the black churches was their adoption of the 'white lie' that Christianity is primarily concerned with an otherworldly reality." (Cone 1969 p. 121). Thus, black Christians endured immense suffering in this world because of their hope for better in the next. Cone was adamant that "Black Theology is an earthly theology!" $(1969$, p. 123) and must emphasise the right to dignity and pursuit of life in this world and this society. A precedent can be found in the "New Thought" theology of an indwelling God, found in Bishop George Hickerson and Wentworth Matthews. See Dorman (2013), pp. 166-73.

102 Ammi (1999), pp. 90-91.

103 Ammi (1999), p. 97. 
fulfilled, and they were taken in ships to a new Egypt, where they lived for four hundred years in servitude, before they again found themselves, and their God, and began the return to righteousness. The marginalised black Americans, the oppressed lower strata of American society, were the focal point of Ben Ammi's thought and the major actors in his narrative. The African American Israelites were always the centre of the narrative- this had been concealed and distorted by the satanic agenda of the Euro-gentiles; but since the Israelites began their movement back to righteousness, the world has adjusted around them. This eschatological reordering, brought about by the revealing of divine truth, has demonstrated where the centre and margins actually lay all along: the AHIJ were the centrepiece.

There are some significant parallels between Ben Ammi's theology of marginalisation and those of Gutiérrez and Cone. Clearly, liberation theology expresses a potent concern for the oppressed and articulates a need to foreground them in the social and theological concerns, just as Ben Ammi's does. Ben Ammi's writing highlights some concepts usually found within liberation theology, especially the biblical motif of social reversal. He writes that: "Salvation will come from the last, not the first, in this world. The momentum has to start at the bottom and carry the outcasts of societies to the top to save this planet earth."104 Ammi also interprets Zechariah 3:1-7's depiction of the messiah riding an ass as indicating it is "the lowly and meek of the people, not the high and mighty" who will lead the way into redemption for humanity; "it is from the midst of that lowly segment of society that the Deliverer will spring forth. He will emerge from amongst those considered left out or dropouts-those appearing to be insignificant." 105 Furthermore, this salvation will precipitate the inversion of the present world order, the high bowing down before the low. Echoing Guttiérez's focus on "those whose human features have been disfigured by oppression, despoliation, and alienation and who have 'no beauty, no majesty' but are the things 'from which men turn away their eyes' (Isa. 53:2-3)". ${ }^{106}$ Ammi writes that "We were despised and rejected of men; we met sorrow and became acquainted with grief. All people hid their faces from us. We were dejected and not esteemed." But now, "Who would believe that a group of black Biblical Israelites, remnants of chattel slaves though miniscule in number, are presently in the Holy Land fulfilling prophecies, activating God's word and unleashing the corrective forces upon the world and all of its inhabitants?"107

While the liberation theologians focus on the New Testament, all these thinkers emphasise the social teachings of the Bible and they all draw the tradition back into the Hebrew Bible, finding there the God of the Oppressed and the God of Liberation, as expressed paradigmatically in the Exodus narrative. Both Gutiérrez and Cone cite Exodus as a "paradigmatic" event-and for Ben Ammi, this prefigures the flight from America in 1967. ${ }^{108}$ In his early text "God's Revelation and Proclamation in History," Gutiérrez argues for the "profound unity of the Old and New Testaments", and, quoting passages from throughout the Hebrew Bible, argues that "the reciprocal relationship between God and the poor person is the very heart of biblical faith." 109 God is essentially liberator, initially of Israel but, as becomes clear later, also of all peoples. ${ }^{110}$ According to Gutiérrez's interpretation, the Hebrew Bible emphasises justice as the principle agenda of the God of Israel, one which His intervention in the world is intended to further in the realm of human lives and affairs; and all humans who have faith in that God are called to further that cause of (social) justice.

\footnotetext{
104 Ammi (1991b), pp. 119-20.

105 Ammi (1991b), p. 121.

106 Gutiérrez (1988), pp. 115-16.

107 Ammi (1991b), p. 151.

108 Gutiérrez (1988), p. 90. For Cone, “The election [of Israel] is inseparable from the event of the Exodus." (1970, p. 18).

109 Gutiérrez (1983), p. 8.

110 Gutiérrez quotes Amos 9:7, “Are not you and the Cushites all the same to me, sons of Israel?-it is Yahweh who speaks. Did not I, who brought Israel out of the land of Egypt, bring the Philistines from Caphtor, and the Aramaeans from Kir?" (1983, p. 11). For Cone, "It is through this act of liberation that "God reveals that he is the God of the oppressed." (1970, p. 19); cf. (1969, pp. 44-45).
} 
Liberation theology, then, finds the theology of marginalisation and liberation to be present foundationally within the Hebrew Bible; and because it is understood as present there and completed in the New Testament, it is by no means an innovation or the special property of Christian scripture. Indeed, the social teachings of the Hebrew Bible have informed much modern Jewish thought, especially in the Reform movement.

But as well as the material conditions which constitute an oppression to be released, there is a mental liberation: "In this dialectic the theology of liberation means the right of the poor to think."111 This is "theological reflection as the right of an exploited and believing people that struggles to throw off the shackles of oppression that drag it into the dust to speak up and tell us about its faith and its hope." 112 Here what we might call the liberation from mental slavery is a separate and equally necessary task, and this is reflected in Ben Ammi's concern for the psychological liberation of his people from centuries of bondage and the Euro-gentile thought values inculcated into them.

However, there are some stark differences too. These are to do with the role of the marginalised, and their eventual relationship to the centre. To begin with the Latin American thinkers, the intent of their theology, as Gutiérrez explains, is that "the poor deserve preference not because they are morally or religiously better than others, but because God is God, in whose eyes 'the last are first'." The question of re-orientation is not present in Latin American liberation theology, because it strives only to improve the lot of the poor, to increase their well-being so that it matches that of other groups, and they are no longer oppressed. The agenda is not to reorient the world around the poor, but rather to incorporate them into a universal gospel. The poor are the locus of Gutiérrez's theology, but only to the extent that they are seen from the outside, and they are liberated from their poverty in order to be incorporated into the mainstream of privilege; to get what the others already have. In fact, one could argue that liberation theology fetishizes poverty in order to release the poor from it; once liberated they are of no further interest. In these respects, it is radically different from Ben Ammi's theology, which is faithful to the biblical narrative of a single chosen people around whom the world should and will orient themselves.

The specificity of James Cone's theology might align it more with Ben Ammi's: both are explicitly concerned with the African American community. There is also a central rereading of blackness into Israelite personages shared by both thinkers. This is particularly relevant because the Black Jesus which Cone argues for is the centrepiece of a re-positioning of the cultural axis, such that the values that emerge from within the oppressed group are the central locus; they are not to be saved by others, but rather manifest salvation themselves, bringing this light unto the world from which others will learn.

He writes,

Concretely, to speak of the presence of Christ today means focusing on the forces of liberation in the black community. Value perspectives must be reshaped in the light of what aids the self-determination of black persons. The definition of Christ as black means that he represents the complete opposite of the values of white culture. He is the center of a black Copernican revolution. ${ }^{113}$

Cone's Black Theology then is a tool by and for the oppressed: it presents the gospel in order that blacks "will see the gospel as inseparable from their humiliated condition, bestowing on them the necessary power to break the chains of oppression."114 So this is not a theology imposed from outside, and the liberation is one that emerges from within that community: "The Christ-event in the twentieth-century is a black-event, that is, an event of liberation taking place in the black community

\footnotetext{
111 Gutiérrez (1983), p. 90.

112 Gutiérrez (1983), p. 90.

113 Cone (1992), p. 149.

114 Cone (1970), p. 23.
} 
in which black people recognize that it is incumbent upon them to throw off the chains of white oppression". ${ }^{115}$ This bears a strong resonance with Ben Ammi's project, in particular his concept of the Power to Define which Cone appears to prefigure, when he relates that in his hometown, black existence was defined by whites in terms of white interests: "White people did everything within their power to define black reality, to tell us who we were-and their definition, of course, extended no further than their social, political, and economic interests."116

However, Cone's Black Theology still differs from Ben Ammi's in its universality: because "blackness signifies oppression and liberation in any society", 117 the theology is not limited to any specific people or society. There is no special role for the African American, and they are producers of this theology only because of their current historical situation: "God, because he is a God of the oppressed, takes sides with black people."118 God's sympathy with and interest in African Americans occurs for no other reason than that they are oppressed. The unstated implication is, of course, that once black people are no longer oppressed, they will stop receiving such divine favour. ${ }^{119}$ They in fact have no greater role in the world than to undergo the process of liberation because God dislikes suffering. This is in clear contrast to Ben Ammi's argument that African Americans are the chosen people with a specific destiny and responsibility to humanity. So, while Cone offers some important elements in solidarity with Ben Ammi, there is still a clear difference.

Therefore what distinguishes Ben Ammi's theology is that it is a specific people who have been marginalised as part of the salvation history of the world; the "lowly segment of society" is not any lowly part of any society, but is specifically African Americans. They are a people who were originally in the centre of the narrative of history but have been marginalised by forces of evil, as punishment for their sins, and only now, as the end nears, are retaking their place.

A principal motivator in Ben Ammi's theology is, of course, literal identification with the Israelites. This profoundly conditions his theology and his approach to the Hebrew Bible; the experiences of Egyptian and Babylonian bondage for Ben Ammi are not merely archetypal incidents, but are the history of his people, and the relationship with God is the same one described therein. Lastly therefore, I will offer a comparison contemporary with liberation theology, but from within Judaism. As black theologians have sought to understand the experience of slavery and segregation through their theology, so Jewish theologians have offered several ways of understanding the Holocaust in terms of Jewish religion; some have sought to reform or reconstruct Judaism, arguing that the prior forms cannot incorporate the events; some have believed that it was possible to place the Holocaust within the existing framework of Judaism. While many options have been explored, only one has attempted to locate the Holocaust within a specifically biblical theology. For Bernard Maza the Holocaust was a punishment after the biblical precedent, for Israel's straying from the path of righteousness, and for their "desire to be like all other nations." ${ }^{120}$ Maza utilises the Hebrew Bible and the warnings of the prophets in order to understand the Holocaust and its relationship to Jewish religion. Maza writes that while the reward would be the redemption from exile and return to the land of Israel, "The road to the Kingdom of HaShem ... would be preceded by 'fury'. Not just fury, but a fury of unprecedented magnitude ... It meant a holocaust." ${ }^{121}$ Part of Maza's reasoning is that the growth of secular ideologies (Zionism, socialism) in eastern Europe demonstrated that the willingness of Jews to bear the sufferings of exile if only they still clung to the Torah had reached its end. This was, then, the last generation that would accept martyrdom with the Name of God on their lips. The martyrdom of the last generation

\footnotetext{
115 Cone (1970), p. 24.

116 Cone (1997), p. 2.

117 Cone (1997), p. 12

118 Cone (1997), p. 26, my emphasis.

119 Victor Anderson (1995) has similarly articulated concerns that in Cone's theology, black people would essentially stop being black once their oppression ended. I extend thanks to my anonymous reviewer for bringing this to my attention.

120 Maza (1986), p. 124.

121 Maza (1986), p. 125.
} 
and the evil they suffered at the hands of their enemies would precipitate the blessing. This line of thought is based on rabbinic interpretation of the Torah-Rashi writes that the Egyptian slavery was "a furnace in which one refines gold", and so just as the suffering of the Israelites made them into "a great nation that would be ready to receive and follow the Torah", ${ }^{122}$ so the Holocaust strengthened the Jewish nation for return to their homeland and the creation of the modern state of Israel. The suffering of the Holocaust is not something that can be understood causally-rather, one must ask what is it for, what is the purpose? And the purpose is evidenced in the creation of the Jewish national home once again.

There is a parallel here with the Hebrew Israelite "theodicy of deserved punishment" as taken from the Hebrew Bible-one which is not found in the liberation theologians. However, while Ben Ammi establishes a trans-ethical mechanism which explains this theodicy, that human freedom has pulled us away from the path of life into the path of death, Maza offers no such consolation-the God envisaged here is expecting martyrs for a deal which cannot be made without human sacrifice. Those who lost their lives were sacrifices to a vengeful God who does, as Key argued, place a singular burden upon his chosen people. Furthermore, there is no hint of a cosmic drama in which the liberation of the people of Israel from their servitude was linked with the coming redemption of all humanity. Therefore, Ben Ammi manages to walk a fine line between these three thinkers, grounding his theology in the Hebrew Bible, while also adapting its strict ethical sensibility to a modern, perhaps even "crypto-scientific" outlook (one where actions determine reactions without the necessity of a moral judge). A key element of this is his identification with the Israelites and the appropriation of the biblical promise.

\section{How This Theology of Marginalisation and Reorientation Has Empowered the AHIJ}

Having looked at how Ben Ammi utilised the theme of marginalisation and argued that his is a unique approach to it, I will now consider how and why this might have functioned to empower his community.

As Gutiérrez implies, there are at least two struggles which any oppressed people must fight in the pursuit of liberation: the external, the structure and system of oppression which presses down upon them; and the internal, the self-perception inculcated by the system of oppression. The latter is arguably more difficult to fully overcome. The question of "how were we oppressed, why did we find ourselves on the bottom of this hierarchy?" is a delicate one. Some will always be tempted to answer according to the narrative of the oppressors: "the fact that we lost this battle indicates that we were inferior." And, therefore, in the pursuit of liberation the natural course is to emulate the victors, to mimic their abilities and capacities and grow in strength such as to be their equals, if this is possible. So, to advance within the existing power structures of education, employment, social mobility. ${ }^{123}$

But the Hebrew Israelite narrative which Ben Ammi developed has taken a different approach: one that views oppression as indicative of high importance, as retribution for a responsibility that went unmet. The victors in this struggle, the "Euro-gentile nations", to use Ben Ammi's terminology, were victorious only because they were being used by God to 'punish' the Hebrews for their sins. The latter had forgotten their God, their language, His laws, His revelation; and so, the responsibility for their predicament was upon them. In this, Ben Ammi asserts a sense of agency in the historical plight of African Americans-they were not victims, but were cause of their own misfortune; their sufferings were not because of inferiority to a more powerful group, but because they had not lived up to their responsibilities set by God-and the mechanisms in place took their toll as the Hebrews veered further from the correct path. Furthermore, this suffering can be permanently overcome by making the choice

122 Maza (1986), p. 8.

123 Ben Ammi notes, "We initially flocked to their educational institutions seeking the tools needed for our survival and development of our countries and societies; instead we received the tools necessary for the maintaining and further development of Euro-gentile countries and societies and the further strengthening of white superiority." (1991b), p. 97. 
to return to God and righteousness. This means that, contrary to Key's assertion that Hebrew Israelite thought infantilises African Americans, in Ben Ammi's thought, their redemption is in their own hands, and culminates in the overthrow of the system which was built around their subjugation. Their redemption (which is an almost mechanical self-redemption, not depending on any passive concept such as 'grace') thus explains and justifies their oppression. So, in this schema, not only was the suffering of slavery meaningful as it was their responsibility, an automatic and deserved punishment, but also the prevention of its recurrence is their responsibility and an end within their reach too.

Ben Ammi does not stop here, however. Because the Israelites were chosen to be a light unto the gentiles, their self-redemption and reclamation of their rightful place will inaugurate the redemption of all humankind. While all humanity had been suffering because of the fall of the Israelites and the dominance of the Euro-gentiles who manifested the spirit of satan, upon remembering themselves and returning to righteousness, the Israelites would now lead the whole world back from the brink of destruction and into a new age unlike any seen before-the Israelites were now set to undo the primal sin of Adam and Eve's disobedience in Eden and the inheritance of death. Thus, his people are propelled to the forefront of the cosmic narrative, with both the push of the terrible memory of American slavery, and the pull of the rediscovered responsibility as leaders among humanity.

While Ben Ammi is certainly a theologian rather than simply a social reformer, and makes no qualms about the validity of his message for all people across the world, he never strays far from his prime concern, which is his own people, the Hebrew Israelites/African Americans who have been enslaved in the USA. As such, identity is a prime factor in Ben Ammi's thought and that of the African Hebrew Israelites generally. Ben Ammi talks constantly in his books about the humiliations of American bondage and the necessity of orienting themselves again towards God and righteousness.

This focus on precisely the identity which was cast outside the mainstream value system of Western society therefore was ripe for inversion: in this case, Ben Ammi transformed the indignities foisted upon black America in the twentieth century into a central role in the cosmic drama: the people were God's chosen, and their current circumstance was simply punishment for their straying, for not living up to their calling. If the people could reclaim their prior righteousness and live according to the rules that God had provided three millennia ago, they could once again ascend to the pinnacle of humanity and form "a light to the gentiles". The marginalised status then was not a result of weakness but a curse which indicated their higher responsibility.

During Ben Ammi's life the world changed immensely: from the civil rights era post-Jim Crow where black leaders were being assassinated by the American state, to the election of Barack Obama; from the curse of Ham to the recognition of Africa as the birthplace of humanity; and the AHIJ went, over the span of decades, from disrespected American underclass to an accepted and successful autonomous community in Israel. ${ }^{124}$ These events were all taken as indicative of the emerging messianic age which was being brought about as a result of the return of the Israelites to righteousness and, to no small extent, the return of the people to the Holy Land.

In this sense then, the Israelites had been marginalised by history, but were always really at the centre of the narrative. Their marginalisation was only apparent, an illusion to be swept away by the truth.

But, in another sense, we can say that Ben Ammi and his community have spent 50 years actively recalibrating the compass of themselves and those around them. This principle of the Power to Define directly empowers the community, by placing in their hands the right to critically analyse the concepts and values which America has instilled in them and to redefine as they see fit based on their own assessment of what is correct, what is meaningful, and what is useful to them and their mission.

124 Many of these events are immortalised in Sar Ahmadiel Ben Yehuda's African Edenic Heritage Museum, described in Jackson (2013), p. 63. 
In this process, they have redefined the Israelites as black Africans; well-being as living a righteous life; holiness as healthiness; spirituality as living as God intends in this world rather than concentrating on the next world; marriage as being not necessarily monogamous (following biblical example); and Israel as being North East Africa. In so doing, they actually orient the world and its values around themselves; the black American outlook which has been marginalised, degraded and ignored, then is no longer being effaced and replaced, but is being held as the gold standard by which the world should live; that which is provided by God. They have redefined the margins as the centre.

It is obvious that any theology which foregrounds liberation as the goal, as the outcome of its own process, presumes and grows from a state of oppression. But we should ask whether a theology grounded in marginalisation requires an eschatology of mainstreaming? The Hebrew Bible, and most of the late second temple Jewish literature, emphasises that in the end of days, all people will be reabsorbed into Israel; the splitting of humanity from Noah's sons and via the confusion of Babel will be reversed, and all will worship the one God through the same language. Thus, the mainstream is absorbed into the marginal, which was always secretly the central current. Other theologies have talked about a final battle between the forces of good and evil wherein the evil would be destroyed; in this case, all else is removed so that there are no margins or centres. Ben Ammi is in some senses an eschatological thinker but he prefers the earlier motif: spiritual evil will be destroyed, and all humans will have their eyes opened to the truth that previously was the preserve of Israel (although even they themselves forgot it for many centuries).

So, in conclusion, the African Hebrew Israelites and specifically Ben Ammi, present a theology which has based itself in historical marginalisation and oppression, interpreting this in line with the biblical text, and making liberation the prime goal. This liberation was the divine destiny of the people, who because of their world-historical role are now set to liberate all of humanity from their blinkered vision, such that the world order can be overturned, and the existing separation of centre and margins are redrawn when everyone else accepts the Hebrew Israelite outlook.

\section{Conclusions}

In this paper, I have looked at the concept of marginalisation and reorientation in Ben Ammi's Hebrew Israelite theology, analysing how he articulated this motif and offered an explanation for it as an important psychological factor in the community's success.

I have shown that the theodicy of deserved punishment is a key element of Ben Ammi's outlook, and therefore of the AHIJ. However, Ben Ammi's development of this motif is deeper and more sophisticated than the thinkers that Andre Key analyses. Key terms the Hebrew Israelite "theodicy of deserved punishment" a "mis-religion", a "theological dehumanising ... which places Black people in the position of justifying their humanity through cosmologies of wretchedness."125 In the case of Ben Ammi though, I argue that it is precisely these theological underpinnings which prevent him from valuing any social reforms because these are directly contrary to the theologically necessary return to righteousness. However, what is more important is the fact that Ben Ammi's mission has been explicitly towards the autonomy of African Americans, a goal which he, like Marcus Garvey, believed was not possible in the framework of the USA; ergo, his emigration out of the USA to the Promised Land was part of the assertion of autonomous self-sufficiency which was a necessary step towards a complete reorientation of values away from the decadence of the west towards a new-old style of living based on both biblical and scientific principles which have arguably been shown to work for those who have consistently adopted them (i.e., those who have become and remained part of the community) far better than those who remained in America and attempted to heal themselves within the framework of oppression. So, where Key writes "The Hebrew Israelite theodicy of deserved punishment requires African Americans to be in a perpetual state of oppression in order to positively

125 Key (2014b), p. 285. 
identify them as the chosen people of God,"126 Ben Ammi demonstrates that the ascension of Israelites out from the status of "African Americans" is what has lifted the curse of oppression and allowed a new messianic state to flower.

Funding: This research received no external funding.

Conflicts of Interest: The authors declare no conflict of interest.

\section{References}

Ammi, Ben. 1990. God, the Black Man, and Truth, Revised ed. Washington, DC: Communicators Press. First published 1982.

Ammi, Ben. 1991a. God and the Law of Relativity. Washington, DC: Communicators Press.

Ammi, Ben. 1991b. The Messiah and the End of This World. Washington, DC: Communicators Press.

Ammi, Ben. 1994. Everlasting Life: From Thought to Reality. Washington, DC: Communicators Press.

Ammi, Ben. 1996. Yeshua the Hebrew Messiah or Jesus the Christian Christ? Washington, DC: Communicators Press.

Ammi, Ben. 1999. An Imitation of Life: Redefining What Constitutes True Life and Living in the New World. Washington, DC: Communicators Press.

Ammi, Ben. 2002. Yeshua the Hebrew Messiah or Jesus the Christian Christ? Part 2: The Final Confrontation. Washington, DC: Communicators Press.

Ammi, Ben. 2004. Revival of the Holy Spirit. Washington, DC: Communicators Press.

Ammi, Ben. 2005. The Resurrection ... from Judgement to Post-Judgement. Washington, DC: Communicators Press. Ammi, Ben. 2010. Physical Immortality: Conquering Death. Washington, DC: Communicators Press.

Ammi, Ben. 2011. Dehumanization: Artificial Intelligence, Technology and the Final Onslaught of the Dominion of Deception. Washington, DC: Communicators Press.

Anderson, Victor. 1995. Beyond Ontological Blackness: An Essay on African American Religious and Cultural Criticism. New York: Continuum.

Avieli, Nir, and Fran Markovitz. 2017. Slavery food, soul food, salvation food: veganism and identity in the African Hebrew Israelite Community. African and Black Diaspora 11: 205-20. [CrossRef]

Batstone, David, Eduardo Mendieta, Lois Ann Lorentzen, and Dwight N Hopkins, eds. 1997. Liberation Theologies, Postmodernity, and the Americas. London: Routledge.

Ben-Israel, Ben Ammi. 1996. The Prophecy. Essence 26: 54.

Cone, James H. 1969. Black Theology \& Black Power. Minneapolis: Seabury Press.

Cone, James H. 1970. A Black Theology of Liberation. Philadelphia and New York: JB Lippincott.

Cone, James. 1992. Jesus Christ in Black Theology. In Liberation Theology: An Introductory Reader. Edited by Curt Cadorette, Marie Giblin, Marilyn J. Legge and Mary Hembrow Snyder. Maryknoll: Orbis, pp. 142-56.

Cone, James H. 1997. God of the Oppressed. Maryknoll: Orbis.

Dorman, Jacob S. 2013. Chosen People: The Rise of American Black Israelite Religions. Oxford and New York: Oxford University Press.

Elkayam, Shelley. 2014. "Food for Peace": The Vegan Religion of the Hebrews of Jerusalem. Idea 26: 317-40. [CrossRef]

Esensten, Andrew. 2019. Yah's Exemplary Soldiers: African Hebrew Israelites in the Israel Defense Forces. Religions 10: 614. [CrossRef]

Gagne, Andrea. 2010. Assasse Pa (The Good Earth): A Study of the African Hebrew Israelites in Ghana. Unpublished Master's dissertation, Hampshire College, Amherst, MA, USA.

Gerber, Israel J. 1977. The Heritage Seekers: Black Jews in Search of Identity. Middle Village: Jonathan David Publishers. Gutiérrez, Gustavo. 1983. The Power of the Poor in History. Maryknoll: Orbis.

Gutiérrez, Gustavo. 1988. A Theology of Liberation: History, Politics, and Salvation. Translated by Caridad Inda, and John Eagleson. Maryknoll: Orbis.

Hare, A. Paul, ed. 1998. The Hebrew Israelite Community. Lanham: University Press of America.

126 Key (2014b), p. 287. 
Jackson, John L., Jr. 2009. All Yah's Children: Emigrationism, Afrocentrism, and the Place of Israel in Africa. Civilizations 58: 93-112. [CrossRef]

Jackson, John L., Jr. 2013. Thin Description: Ethnography and the African Hebrew Israelites of Jerusalem. Cambridge: Harvard University Press.

Key, Andre E. 2014a. If thou do not hearken unto the voice of the Lord thy God: A Critique of Theodicy in Black Judaism. Black Theology 12: 267-88. [CrossRef]

Key, Andre E. 2014b. Toward a Typology of Black Hebrew Religious Thought and Practice. Journal of Africana Religions 2: 31-66. [CrossRef]

Könighofer, Martina. 2008. The New Ship of Zion: Dynamic Diaspora Dimensions of the African Hebrew Israelites of Jerusalem. Wien: Lit Verlag.

Landing, James E. 2002. Black Judaism: The Story of an American Movement. Durham: Carolina Academic Press.

Lincoln, Eric C. 1973. The Black Muslims in America. Boston: Beacon Press.

Lounds, Morris, Jr. 1981. Israel's Black Hebrews: Black Americans in Search of Identity. Washington, DC: University Press of America.

Markowitz, Fran. 1996. Israel as Africa, Africa as Israel: 'Divine Geography' in the Personal Narratives and Community Identity of the Black Hebrew Israelites. Anthropological Quarterly 69: 193-205. [CrossRef]

Markowitz, Fran. 2000. Millenarian Motherhood: Motives, Meanings and Practices among African Hebrew Israelite Women. Nashim: A Journal of Jewish Women's Studies E Gender Issues 3: 106-38.

Markowitz, Fran. 2005. Claiming the Pain, Making a Change: The African Hebrew Israelite Community's Alternative to the Black Diaspora. In Homelands and Diasporas. Edited by Andre Levy and Alex Weingrod. Stanford: Stanford University Press.

Markowitz, Fran, Sara Helman, and Dafna Shir-Vertesh. 2003. Soul Citizenship: The Black Hebrews and the State of Israel. American Anthropologist 105: 302-12. [CrossRef]

Maza, Bernard. 1986. With Fury Poured Out: A Torah Perspective on the Holocaust. New York: KTAV.

Michaeli, Ethan. 2000. Another Exodus: The Hebrew Israelites from Chicago to Dimona. In Black Zion. Edited by Yvonne Chireau and Nathaniel Deutsch. Oxford: Oxford University Press, pp. 73-90.

Miller, Michael T. Forthcoming. The African Hebrew Israelites of Jerusalem: A Borderline Case. In Jewish Perspectives on the Stranger. Edited by Catherine Bartlett. London: Brill.

Sheen, David. 2011. Recalling their show of strength. Haaretz. April 22. Available online: https://www.haaretz. com/1.5002908 (accessed on 12 February 2020).

Singer, Merrill Charles. 1979. Saints of the Kingdom: Group Emergence, Individual Affiliation, and Social Change among the Black Hebrews of Israel. Unpublished Ph.D. dissertation, University of Utah, Salt Lake City, UT, USA.

Singer, Merrill. 2000. Symbolic Identity Formation in an African American Religious Sect: The Black Hebrew Israelites. In Black Zion. Oxford: Oxford University Press, pp. 55-72.

Stonequist, Everett V. 1937. The Marginal Man: A Study in Personality and Culture Conflict. New York: Russell \& Russell.

Weisbord, Robert G. 1975. Israel and the Black Hebrew Israelites. Judaism 24: 23-38.

(C) 2020 by the author. Licensee MDPI, Basel, Switzerland. This article is an open access article distributed under the terms and conditions of the Creative Commons Attribution (CC BY) license (http://creativecommons.org/licenses/by/4.0/). 